\title{
Investigation on Effect of Acid Wash with Thermocol Ball on Physical Properties of Knitted Garments
}

\author{
Elias Khalil, Masud Rana, Jewel Faria, Md. Al-Amin Islam, Md. Sohel Rana \\ Department of Textile Engineering, World University of Bangladesh, Dhaka, Bangladesh \\ Email: eliaskhalil52@gmail.com,ranatex7@gmail.com,jewelahmed297@gmail.com, \\ adislam601@yahoo.com, asohel992@gmail.com
}

Received 1 February 2016; accepted 2 May 2016; published 5 May 2016

Copyright (C) 2016 by authors and Scientific Research Publishing Inc.

This work is licensed under the Creative Commons Attribution International License (CC BY). http://creativecommons.org/licenses/by/4.0/

\section{(c) (i) Open Access}

\section{Abstract}

Washing is considered as the final process of garments finishing. Acid washing is one kind of finishing treatment used for making sewn garments aesthetic, fashionable, soft, comfortable and also adding value to the final garments. This paper investigates the effect of the acid washing (with thermocol balls and potassium permanganate) on different physical properties of three knitted garments (Single Jersey 100\% Cotton T-shirt, Single Jersey 95\% Cotton 5\% Spandex T-Shirt and 1 $\times 1 \mathrm{Rib} 100 \%$ Cotton T-Shirt). Typical washing procedures and techniques were followed and then physical properties were analyzed under standard condition. It is observed that fabric weight, CPI, WPI, spirality and shrinkage increase while bursting strength, stitch length absorbency decrease after washing treatment. $\mathrm{pH}$ of all the samples is under controlled and lies between 7 to 8 . There is no change in pilling, colorfastness to wash, water and dry rubbing while a little bit decrease in wet rubbing.

\section{Keywords}

Acid Wash, Potassium Permanganate, Thermocol Ball, Physical Properties, Knitted Garments

\section{Introduction}

Nowadays, faded textile products have become very popular among the young customers all over the world [1]. For this reason, textile manufacturers are trying to develop numerous techniques to improve the visual outlook 
of the sewn garments [2]-[5]. Different denim washing techniques have been developed and used on different materials to create a large variety of designs for trendy denim garments and jeans [6]-[11]. Nowadays along with denim washing knit garments such as T-shirt, Polo shirt, and trouser, are also washed by using different techniques such as enzymes wash, softener wash, Silicone wash, tie dye wash, pigment wash, caustic wash, etc. are used to create or enhance the physical and mechanical property changes [12] [13].

Acid washing in knitted garments is a new technique which is done by potassium permanganate and pumice stone or other substitutes [13] [14].

Potassium permanganate is an inorganic chemical compound with the chemical formula $\mathrm{KMnO}_{4}$ [15]. It is a strong oxidizing agent and used to make color fading effect on sewn garments [16]-[18]. Sometimes it is used at the point of hand sand area or without hand sand area. As it is a great oxidizing agent, after applying, it is necessary to neutralize the garments by any good neutralizing agent [19].

Thermocol is a commercial name. In 1951, the researchers of a German company named BASF successfully restructured chemical bonding of polystyrene (a synthetic petroleum product) molecules and developed a substance named stretch polystyrene. This substance was named Thermocol, which nowadays is manufactured through a simple process. Thermoplastic granules are expanded through application of steam and air. Expanded granules become much larger in size but remain very light, formable, \& rigid [20]-[23].

Small thermocol balls $(0.75-1 \mathrm{~cm}$ diameter) are being used as a substitute of pumice stone in garments finishing process [24] [25].

Elias et al. (2015) studied the effect of change in concentration of $\mathrm{KMnO}_{4}$ and processing time on physico-mechanical properties of denim jeans during acid washing. It was found that the tensile strength, seam strength, stiffness and fabric weight were decreased after application of potassium permanganate with increasing processing time during washing treatment while yarn count (Ne), EPI, PPI and dimensional change were increased [26]-[28].

Solaiman et al. (2015) investigated the effect of three types of washing (enzyme, softener, Silicone) on Physical and Mechanical Properties on five types of following knitted garments: 100\% cotton Single Jersey T-shirt, Slub Single Jersey T-shirt, Double Lacoste (5\% Lycra) Polo shirt, Single jersey CVC (T-shirt) and PC single Jersey (T-shirt). The results showed that when enzyme wash was applied on the knit garments, it improved all the tested properties of knit garments, and it also reduced the hairy fibers from the fabric surface. Similar results were found in case of Silicone and softener wash as well [29].

However, the effect of acid wash with thermocol balls and potassium permanganate on physico mechanical properties on knitted garments was not studied in the past research. In this present study, three knitted garments (Single Jersey 100\% Cotton T-shirt, Single Jersey 95\% Cotton 5\% T-Shirt and $1 \times 1$ Rib100\% Cotton T-Shirt) were washed with $\mathrm{H}_{3} \mathrm{PO}_{4}, \mathrm{KMnO}_{4}$ along with thermocol balls and various properties were analyzed according to standard methods.

\section{Materials and Methods}

\subsection{Garments Samples}

Following three types of reactive dyed knitted garments were used for this research:-

1) Single Jersey (S/J) T-Shirt (100\% cotton), GSM 140 ;

2) Single Jersey (S/J) T-Shirt (95\% Cotton 5\% Spandex), GSM 159;

3) $1 \times 1$ Rib T-Shirt (100\% Cotton), GSM 138 .

\subsection{Chemicals}

Phosphoric acid $\left(\mathrm{H}_{3} \mathrm{PO}_{4}\right.$, Yalong, China) and potassium permanganate $\left(\mathrm{KMnO}_{4}\right.$, GC, China), Jet (an anionic detergent, Bangladesh).

\subsection{Washing Machine}

- Before Brand Name-Ngai Shing Development Limited;

- M/C capacity-20 kg;

- RPM (Revolution per minute)-30 - 33 rpm;

- Origin-Hong Kong. 


\subsection{Acid Washing}

At first make a solution (5\% phosphoric acid and $15 \mathrm{~g} / \mathrm{L}$ potassium permanganate)

$$
\downarrow
$$

Thermocol balls are taken into the washing machine

(Thermocol balls $0.1 \%$ on the weight of garment)

$$
\downarrow
$$

Sprinkle the solution into the machine

$$
\downarrow
$$

Run the machine for 5 min

(For ensuring all the balls get wetted completely)

$$
\downarrow
$$

Load the garments into the machine and washing process carried out for 15 min at normal temperature

$$
\downarrow
$$

Unload the garments from the machine

$$
\downarrow
$$

Cold wash by automatic washing machine (Front loading)

Detergent $1 \mathrm{gm} / \mathrm{L}$ (For $10 \mathrm{~min}$ at $30^{\circ} \mathrm{C}$ temperature)

$$
\text { Drain the bath }
$$

$\downarrow$

Neutralization with Sodium metabisulfite $\left(3 \mathrm{gm} / \mathrm{L}\right.$ for $5 \mathrm{~min}$ at $\left.45^{\circ} \mathrm{C}\right)$

$$
\downarrow
$$

Drain the bath

$\downarrow$

Unload the garments on trolley

$\downarrow$

Hydro extracting

$\downarrow$

Drying the garments (By tumble dryer for $15 \mathrm{~min}$ at $70^{\circ} \mathrm{C}$ temperature)

Washed goods

\subsection{Testing and Analysis}

Fabric weight was measured according to ASTM D 3776 method [30] and according to BS EN 14970-2006, stitch length was measured [31]. According to AATCC 8 standard both the dry and wet rub tests were done [32]. For absorbency testing, AATCC 79 method was followed [33]. CPI and WPI of the fabric was calculated by counting the number of the Coarses and wales contents in 1 inch of the fabric. IS 1963 method was used for this measurement [34]. According to ASTM D 2259, shrinkage of these sample garments were tested [35]. Bursting strength of samples was measured by an automatic bursting strength tester. Samples are gradually set on the diaphragm, the automatic bursting strength tester, measures time, distortion, pressure \& the flow rate to burst the fabric. It was done according to ASTM D3786 [36]. AATCC 81-2006 method was used for measuring $\mathrm{P}^{\mathrm{H}}$ of the fabric [37]. Spirality (Dimensional change) was measured according to AATCC Test Method 187-2013 [38]. Pilling test of Single Jersey and Rib fabric was done according to ISO 12945-1:2001 [39]. Color fastness to washing and water were determined respectively according to ISO 105-C10 and ISO 105-E01 [40] [41].

\section{Results and Discussions}

In this article, the change of physical and mechanical properties due to the washing treatment has been investigated. The overall results are shown in Table 1. From this table, it is seen that the weight of the fabric increases for each garments. This increase is high in case of $1 \times 1$ Rib garments (13.76\%). Actually when the knitted garments are faced with frictional action due to the thermocol balls and rotating cylinder of the washing machine, a trace of solution of $\mathrm{KMnO}_{4}$ and $\mathrm{H}_{3} \mathrm{PO}_{4}$ also get penetrated into the fiber structure causing change in internal 
Table 1. Effect of acid wash on physical properties of different cotton knitted garments.

\begin{tabular}{|c|c|c|c|c|c|c|c|}
\hline \multirow{2}{*}{\multicolumn{2}{|c|}{ Properties }} & \multicolumn{2}{|c|}{$\begin{array}{c}\text { Single Jersey } 100 \% \text { Cotton } \\
\text { T-Shirt }\end{array}$} & \multicolumn{2}{|c|}{$\begin{array}{c}\text { Single Jersey 95\% Cotton 5\% } \\
\text { Spandex T-Shirt }\end{array}$} & \multicolumn{2}{|c|}{$\begin{array}{c}1 \times 1 \text { Rib100\% Cotton } \\
\text { T-Shirt }\end{array}$} \\
\hline & & $\begin{array}{l}\text { Before } \\
\text { Wash }\end{array}$ & $\begin{array}{l}\text { After } \\
\text { Wash }\end{array}$ & Before Wash & After Wash & Before Wash & $\begin{array}{l}\text { After } \\
\text { Wash }\end{array}$ \\
\hline \multicolumn{2}{|c|}{ Fabric Weight (GSM) } & 140 & 142 & 159 & 169 & 138 & 157 \\
\hline \multicolumn{2}{|c|}{ Bursting Strength (KPa) } & 354.5 & 332.1 & 367.5 & 349.3 & 369.4 & 363 \\
\hline \multicolumn{2}{|c|}{ Coarse Per Inch (CPI) } & 50 & 52 & 60 & 62 & 44 & 48 \\
\hline \multicolumn{2}{|c|}{ Wale Per Inch (WPI) } & 34 & 35 & 40 & 42 & 44 & 46 \\
\hline \multicolumn{2}{|c|}{$\mathrm{pH}$} & 7.5 & 7 & 8 & 7.5 & 8 & 7 \\
\hline \multirow{2}{*}{$\begin{array}{l}\text { Colorfastness to } \\
\text { Rubbing }\end{array}$} & Dry & 4.5 & 4.5 & 4.5 & 4.5 & 4.5 & 4.5 \\
\hline & Wet & 4.5 & 4 & 4.5 & 4 & 4.5 & 4 \\
\hline \multicolumn{2}{|c|}{ Spirality (\%) } & 2 & 3 & 1 & 2 & 1 & 2 \\
\hline \multicolumn{2}{|c|}{ Water Absorbency (Sec) } & 33 & 44 & 39 & 40 & 43 & 60 \\
\hline \multicolumn{2}{|c|}{ Colorfastness to Washing } & 4.5 & 4.5 & 4.5 & 4.5 & 4.5 & 4.5 \\
\hline \multicolumn{2}{|c|}{ Colorfastness to Water } & 4.5 & 4.5 & 4.5 & 4.5 & 4.5 & 4.5 \\
\hline \multicolumn{2}{|c|}{ Stitch Length (mm) } & 2.9 & 2.5 & 2.95 & 2.20 & 2.75 & 2.30 \\
\hline \multirow{2}{*}{ Shrinkage (\%) } & Lengthwise & 1 & 2 & 2 & 3 & 4 & 6.66 \\
\hline & Widthwise & 1 & 2 & 2 & 2.8 & 1 & 1.5 \\
\hline \multirow{2}{*}{ Pilling Resistance } & Warp & 4.5 & 4.5 & 4.5 & 4.5 & 4.5 & 4.5 \\
\hline & Weft & 4.5 & 4.5 & 4.5 & 4.5 & 4.5 & 4.5 \\
\hline
\end{tabular}

tension in the constituted molecules. The garments then tended to revert its more dimensions that results in the contraction of the yarns. This effect causes the reduction of the stitch length also increase stitch density for higher value of CPI and WPI. Thus weight of the garments, spirality and shrinkage increase after washing.

It is also found that the acid washing treatment of the knitted garments causes significant decrease in tensile strength (bursting strength). Maximum strength loss (6.31\%) occurred in case of $100 \%$ cotton single jersey T shirt. At first thermocol balls with solution breaks the chemical bond of the primary wall of the cellulose molecules and after that it attacked slightly on secondary wall. The result of this reaction is that the primary wall of the cotton fiber is loosened and broken down quicker with the mechanical forces of washing machine and rough surface of thermocol balls. As a result, internal bonding force among the molecules of the cellulose gets reduced which causes lower tensile strength. No significant change was occurred in fabric $\mathrm{pH}$ as mild concentration of acid was used.

It is also found from the table that color fastness properties against washing, water and dry rubbing were unchanged while wet rubbing property is deteriorated a bit. After washing, absorbency reduced as the treatment changes the interfacial tension of the fiber molecules. The washed garments showed better pilling resistance.

\section{Conclusion}

Acid washing treatment with thermocol balls has greater effect on the physical and mechanical properties of knitted garments. In every case, it was found that the weight of the garments increased but bursting strength decreased after washing. This experiment will help the personnel related with the industrial washing process as well as researcher in this field. Although we conducted this experiment on single jersey and rib fabric only, similar results might be found for other knitted structure.

\section{References}

[1] Card, A., Moore, M.A. and Ankeny, M. (2005) Performance of Garment Washed Denim Blue Jeans. AATCC Review, 5, 28-31. 
[2] Sariisik, M. (2004) Use of Cellulases and Their Effects on Denim Fabric Properties. AATCC Review, 4, 24-29.

[3] Cavaco-Paulo, A. (1998) Mechanism of Cellulase Action in Textile Processes. Carbohydrate Polymers, 37, $273-277$. http://dx.doi.org/10.1016/S0144-8617(98)00070-8

[4] Özdil, N., Özdoğan, E. and Öktem, T. (2003) Effects of Enzymatic Treatment on Various Spun Yarn Fabrics. Fibres \& Textiles in Eastern Europe, 4, 58-61.

[5] Cheung, H.F., Kan, C.W., Yuen, C.W.M., Yip, J. and Law, M.C. (2013) Colour Fading of Textile Fabric by Plasma Treatment. Journal of Textiles. http://dx.doi.org/10.1155/2013/214706

[6] Sarkar, J., Khalil, E. and Solaiman, M. (2014) Effect of Enzyme Washing Combined with Pumice Stone on the Physical, Mechanical and Color Properties of Denim Garments. International Journal of Research in Advent Technology, 2, 65-68.

[7] Sarkar, J. and Khalil, E. (2014) Effect of Industrial Bleach Wash and Softening on the Physical, Mechanical and Color Properties of Denim Garments. IOSR Journal of Polymer and Textile Engineering, 1, 46-49. http://dx.doi.org/10.9790/019X-0134649

[8] Khalil, E. (2015) Sustainable and Ecological Finishing Technology for Denim Jeans. AASCIT Communication, 2, 159163.

[9] Khalil, E. and Islam, M.M. (2015) Wrinkle Finish on Denim by Resin Treatment: A Review. AASCIT Communication, 2, 82-87.

[10] Sarkar, J, Khalil, E. and Rahman, A. (2015) Technical Study of the Effect of $\mathrm{CO}_{2}$ Laser Surface Engraving on the Physical Properties of Denim Fabric. International Conference on Mechanical Industrial and Materials Engineering (ICMIME), RUET.

[11] Kan, C.W. (2015) Washing Techniques for Denim Jeans. In: Paul, R., Ed., Denim: Manufacture, Finishing and Applications, Woodhead Publishing, Cambridge, 313-256. http://dx.doi.org/10.1016/b978-0-85709-843-6.00011-1

[12] Solaiman, M., Rahman, M.M., Khalil, E. and Sarkar, J. (2014) Consequences of Enzyme Rinse on Physical Properties of Knit Garments. International Journal of Research in Advent Technology, 2, 112-116.

[13] Islam, M. Types of Wash Applied on Knit Garments. Retrieved on 31 January 2016. http://www.garmentsmerchandising.com/types-of-wash-applied-on-knit-garments/

[14] Gokarneshan, N., Durairaj, C., Krishnamurthy, P., Shanmugasundaram, S., Subhash, R. and Su, P. (2009) Chemical Finishing and Washing of Knit Wear. http://www.fibre2fashion.com/industry-article/23/2210/chemical-finishing-and-washing-of-knit-wear1.asp

[15] Potassium Permanganate. Wikipedia, the Free Encyclopedia. Retrieved 31 January 2016. https://en.wikipedia.org/w/index.php?title=Potassium_permanganate\&oldid=702493323

[16] Lin, L.X. (2009) Finishing of Jeans Clothing. Dyeing Finish, 35, 29-34.

[17] Zheng, Z.Q. (2009) A Research on Washing Art Effect of Cowboy Lining. Shandong Textile Economy, 2009, 111-112, 115.

[18] Zhao, W.B. (2008) Common Denim Washing Technologies. Dyeing Finish, 34, 34-36. (In Chinese)

[19] Rahman, M.S. (2014) Practical Handbook of Washing and Dyeing. University Campus Publishing, Dhaka, 73.

[20] Agham Rahul, D. (2012) State-of-the-Art Insulation Materials: A Review. International Journal of Engineering and Innovative Technology, 2, 97-102.

[21] What Is Thermocol? And What Is Its Manufacturing Process? Retrieved on 31 January 2016. http://www.herebeanswers.com/2010/02/thermocol-and-its-manufacturing.html

[22] Product Literature (SARAFINISH-OMP) of Sarex Chemicals (India). Retrieved on 31 January 2016. http://www.sarex.com/LIT/PY080.PDF

[23] Polystyrene. Wikipedia, the Free Encyclopedia. Retrieved 31 January 2016. https://en.wikipedia.org/w/index.php?title=Polystyrene\&oldid=702317764

[24] Garments Processing. Retrieved on 31 January 2016. http://www.fibre2fashion.com/industry-article/technology-industry-article/garment-processing/garment-processing1.asp

[25] Retrieved on 31 January 2016. http://www.motherlandgarments.com/services.html

[26] Khalil, E., Rahman, A. \& Solaiman, M. (2015) Investigation on Simultaneous Effect of $\mathrm{KMnO}_{4}$ Concentration and Processing Time on Tensile Strength, Weight and Stiffness of Denim Jeans During Acid Washing with Pumice Stone. International Journal of Research \& Review, 2, 546-550.

[27] Khalil, E. (2015) Investigation of the Influence of Potassium Permanganate on Denim Jeans Processing during Acid Wash. AASCIT Communication, 2, 271-275. 
[28] Khalil, E. (2015) Effect of Processing Time and Concentration of Potassium Permanganate on Physico-Mechanical Properties of Denim Jeans during Stone Washing. Science Innovation, 3, 68-71. http://dx.doi.org/10.11648/j.si.20150306.12

[29] Solaiman, Rouf, A., Rasel, S. and Khalil, E. (2015) Investigation of Different Washing Effects on Physical and Mechanical Properties of Cotton Knitted Garments. Journal of Textile Science and Technology, 1, 101-109. http://dx.doi.org/10.4236/jtst.2015.13011

[30] ASTM D3776/D3776M-09a (2013) Standard Test Methods for Mass per Unit Area (Weight) of Fabric. ASTM International, West Conshohocken.

[31] BS EN 14970:2006 (2006) Textiles. Knitted Fabrics. Determination of Stitch Length and Yarn Linear Density in Weft Knitted Fabrics.

[32] ISO 105-X12:2001 (2001) Textiles-Tests for Color Fastness—Part X12: Color Fastness to Rubbing.

[33] AATCC Test Method 79 (2009) Absorbency of Textiles. American Association of Textile Chemists and Colorists, AATCC Technical Manual, Research Tri USA.

[34] IS 1963 (1982) Methods for Determination of Threads per Unit Length in Knitted Fabrics. Bureau of Indian Standards, New Delhi.

[35] AATCC Test Method 96 (2009) Dimensional Changes in Commercial Laundering of Woven and Knitted Fabrics except Wool. American Association of Textile Chemists and Colorists, Research Triangle Park.

[36] ASTM D3786/ (2013) Standard Test Method for Bursting Strength of Textile Fabrics, Diaphragm Bursting Strength Tester Method. West Conshohocken.

[37] AATCC Test Method 81-2006 (2006) pH of the Water Wet Processed Textiles. American Association of Textile Chemists and Colorists, AATCC Technical, Research Triangle Park.

[38] AATCC Test Method 187-2013 (2013) Dimensional Changes of Fabrics: Accelerated. American Association of Textile Chemists and Colorists, Research Triangle Park.

[39] BS EN ISO 12945-1:2001 Textiles. Determination of Fabric Propensity to Surface Fuzzing and to Pilling. Pilling Box Method.

[40] ISO 105-C10:2006 (2006) Textiles-Tests for Color Fastness-Part C10: Color Fastness to Washing with Soap or Soap and Soda.

[41] ISO 105-E01:2013 Textiles-Tests for Color Fastness-Part E01: Color Fastness to Water. 